VERTAISARVIOITU

KOLLEGIALT GRANSKAD

PEER-REVIEWED

www.tsv.fi/tunnus

\title{
KOLTANSAAMEN NÄÄTÄMÖN MURTEEN JA MERISAAMEN VÄLINEN KOODIEN SEKOITTUMINEN VUONNA $1920^{1}$
}

\author{
Markus Juutinen, Oulun yliopisto, Giellagas-instituutti
}

Tässä artikkelissa tutkin koltansaamen Näätämön murteen ja pohjoissaamen merisaamen murteen välistä koodien sekoittumista. Tutkimusaineistona käytän kahdelta kaksikieliseltä puhujalta vuonna 1920 Norjan Näätämössä kerättyjä folkloretekstejä. Aineiston kerääjän Eliel Lagercrantzin mukaan osa teksteistä on merisaamea ja osan kieltä hän kuvailee termillä koltansaamen ja merisaamen sekakieli.

Tutkimuksessa selvisi, että tekstit sisältävät kolme erilaista rekisteriä: koltansaame, merisaame sekä rekisteri, jota kutsun koltansaame-merisaamerekisteriksi. Kaksi ensimmäistä rekisteriä sisältävät lyhyitä koodinupotuksia toisesta kielestä. Koltansaame-merisaame-rekisteri sisältää sekä kielioppia että sanastoa molemmista kielistä. Kutsun tätä kongruentiksi leksikalisaatioksi. Koska kielet ovat lähisukukieliä ja jakavat sekä perussanaston että paljon yhteisiä kieliopillisia rakenteita, puhuja voi täyttää kielten yhteiset kieliopilliset rakenteet molempien kielten sanastolla. Lisäksi tutkimuksessa kävi ilmi, että aineisto sisältää sekä äänteellisiä että kieliopillisia hybridimuotoja. Äänteelliset hybridimuodot sisältävät äänteellisiä piirteitä molemmista kielistä, kun taas kieliopillisissa hybridimuodoissa yhdestä kielestä peräisin olevaa sanaa on taivutettu toisen kielen mukaisesti.

Avainsanat: kielikontaktit, koltansaame, koodien sekoittuminen, pohjoissaame

${ }^{1}$ Artikkeli on kirjoitettu Suomen Kulttuurirahaston apurahan turvin.

Kirjoittajan yhteystiedot:

Markus Juutinen

markus.juutinen@oulu.fi

\section{JOHDANTO}

Tässä artikkelissa tutkin koodien sekoittumista koltansaamen Näätämön murteen ja pohjoissaamen Etelä-Varangissa puhutun merisaamen murteen välillä. Tutkimusaineistona käytän Eliel Lagercrantzin vuonna 1920 
kahdelta kaksikieliseltä kolttasaamelaisilta keräämiä tekstejä (Lagercrantz, 1961). Lagercrantz pitää osaa teksteistä merisaamena ja osan kieltä hän kuvailee meri- ja koltansaamen sekamurteeksi (see-und skoltelappischer Mischdialekt) (Lagercrantz, 1961, s. 172).

Saamelaiskielet jaetaan tavallisesti kahtia länsi- ja itäsaamelaisiin kieliin (Korhonen, 1981, s. 18-19; Sammallahti 1998, s. 6-7). Pohjoisen Jäämeren rannalla niiden välinen raja kulki länsisaamelaisen pohjoissaamen merisaamelaismurteiden ja itäsaamelaisen koltansaamen nykyisin jo sammuneen Näätämön murteen välillä. Maantieteellisen läheisyyden lisäksi myös nämä kielimuodot ovat suhteellisen lähellä toisiaan. Selvien kontakteista johtuvien samankaltaisuuksien lisäksi merisaamessa tavataan myös eräitä vanhoja itäsaamelle tyypillisiä piirteitä (Korhonen, 1964, s. 60-61). Vaikka Näätämön murre luokitellaan tutkimuskirjallisuudessa koltansaamen pohjoismurteisiin kuuluvaksi omaksi murteekseen (Itkonen, 1958, s. XXXVII; Korhonen, 1981, s. 16; Sammallahti, 1998, s. 30-32), sen erityispiirteitä ja suhdetta muihin saamelaisiin kielimuotoihin on käsitelty tutkimuskirjallisuudessa erittäin vähän. Kattavimman kuvauksen on esittänyt Lagercrantz (1961, s. 172-173, 187-188) julkaisemiensa tekstien yhteydessä, mutta hänenkin kuvauksensa koostuu vain yksittäisistä huomioista keräämiensä tekstien kielestä sekä Näätämön murteen ja Varangin alueen merisaamen eroista. Suurin syy vähäiseen kiinnostukseen Näätämön murretta kohtaan on ilmeisesti ollut se, että sitä pidettiin pohjoissaamen sekaisena ja siksi vähemmän kiinnostavana kuin muita "puhtaampina" pidettyjä koltansaamen murteita.

Saamelaiskielten kielikontaktitutkimuksissa on keskitytty lähinnä saamelaiskielten ja enemmistökielten välisiin historiallisiin kontakteihin, ja erityisesti lainasanatutkimukseen. Reaaliaikaisia kielikontakteja ei juurikaan ole tutkittu. Myös saamelaiskielten väliset kielikontaktit ovat jääneet muiden tutkimusaiheiden varjoon. Yksi syy tähän on se, että yksittäisten saamelaiskielten tutkimuksessa tutkimuksen keskiössä ovat olleet kielten keskeisimmät ja suurimmat murteet kielten rajaseuduilla sijaitsevien murteiden jäädessä vähemmälle tarkastelulle.

Tässä tutkimuksessa turvaudun metodologisesti Muyskenin (2000) koodinsekoittumismalliin. Termillä koodinsekoitus (codemixing) tarkoitan yleisellä tasolla tilannetta, jossa kahden kielen sanastoa ja kielioppia esiintyy samassa puhetilanteessa. Se voi tarkoittaa koodinupotuksia (insertion), jossa yhden kielen aineksia esiintyy toisen kielen määrittämässä lauseessa, koodien vuorottelua (alternation), jossa eri kielten lauseet seuraavat toisiaan vaikuttamatta toisensa kielioppeihin, tai kongruenttia leksikalisaatiota (congruent lexicalization), joka tarkoittaa tilannetta, jossa puhuja täyttää eri kielten sanastolla kielten yhteiset kieliopilliset rakenteet. Tutkimusaineistossani esiintyy sekä koodinupotuksia että kongruenttia leksikalisaatiota.

Artikkelin rakenne on seuraava: Luvussa 2 käyn läpi Näätämön ja Etelä-Varangin historiaa erityisesti niiltä osin, jotka liittyvät alueen monikielisyyteen ja kielikontakteihin. Luvussa 3 esittelen käyttämäni aineiston sekä avaan Lagercrantzin informanttien taustoja. Luvussa 4 esittelen käyttämäni metodin sekä teoriataustan. Luvussa 5 erittelen Lagercrantzin keräämien tekstien sisältämää koodien sekoittumista. Esittelen Lagercrantzin informanttien kielellisten repertuaarien eroavaisuuksia ja niiden sisältämää koodien sekoittumista. Luvussa 6 esittelen teksteissä esiintyviä äänteellisiä ja kieliopillisia hybridimuotoja. Äänteellisellä hybridimuodolla tarkoitan muotoa, jossa on äänteellisiä piirteitä kahdesta kielestä. Kieliopillisella hybridimuodolla tarkoitan 
tapausta, jossa yhden kielen sanaa on taivutettu toisen kielen kieliopin mukaan. Luvussa 7 kokoan artikkelin tulokset yhteen. Vaikka koltansaame ja merisaame kuuluvat saamelaiskielten eri haaroihin, kaksikielisten puhujien kielitajussa niiden välinen raja ei ole suuri. Puhujat voivat yhdistellä osaamiaan kieliä eri tavoin, eikä aina ole selvää, mihin kieleen jokin ilmaus kuuluu. Luvussa 8 liitän tämän tutkimuksen laajempaan saamelaiskielten välisten kielikontaktien kuvaan.

\section{NÄÄTÄMÖN HISTORIA}

1800-luvun alkuun asti Norjan Etelä-Varanki oli lähes yksinomaan saamelaisten asuttama alue. Merisaamelaisten olivat alueen suurin väestöryhmä ja pohjoissaame toimi alueen enemmistökielenä, jota myös monet kolttasaamelaiset käyttivät arkikielenään (Wi- kan, 1995, s. 90-91). Merisaamelaisten lisäksi alueella oli myös paljon pohjoissaamea puhuvia poronhoitajia (Wikan, 1995, s. 186). Suomalaisten 1830-luvulla alkanut Etelä-Varankiin suuntautunut muuttoaalto muutti nopeasti alueen etnistä koostumusta. Suomalaisia muutti paljon esimerkiksi Vesisaareen sekä Näätämöön, joiden lisäksi heitä asettui asumaan myös lännemmäksi Ruijan rannikolle (Lähteenmäki, 2004, s. 384-387; Wikan, 1995, 93-102). Taulukosta 1. käy ilmi, että 1900-luvun alussa pohjoissaamea puhuva väestöryhmä oli reilusti suurin EteläVarangin ihmisryhmistä, mutta heidän suhteellinen osuutensa pieneni suomalaisten ja norjalaisten muuton myötä. Tilastosta käy myös ilmi, että kolttasaamelaiset olivat koko tarkasteluajan todella pieni väestöryhmä ja esimerkiksi pohjoissaamea puhuneita oli alueella moninkymmenkertainen määrä.

Taulukko 1. Etelä-Varangin väestöryhmien lukumäärä väestönlaskun mukaan (Lunde, 1979, s. 132)

\begin{tabular}{|l|l|l|l|l|l|l|l|l|l|}
\hline & Suomalaisia & $\begin{array}{l}\text { Koltta- } \\
\text { saamelaisia }\end{array}$ & $\begin{array}{l}\text { Pohjois- } \\
\text { saamelaisia }\end{array}$ & Norjalaisia & & Yht. \\
\hline Vuosi & Lukumäärä & $\%$ & Lukumäärä & $\%$ & Lukumäärä & $\%$ & Lukumäärä & $\%$ & \\
\hline 1855 & 176 & 18 & 24 & 2 & 596 & 60 & 226 & 22 & 998 \\
\hline 1890 & 862 & 45 & 18 & 1 & 733 & 38 & 337 & 17 & 1932 \\
\hline 1910 & 900 & 26 & 26 & 1 & 742 & 21 & 1928 & 54 & 3570 \\
\hline
\end{tabular}

Näätämön siida (Njauddâm) eli Näätämön kolttasaamelaisten yhteisö alueineen, sijaitsi Norjan Etelä-Varangissa sekä Koillis-Inarissa Sevettijärven alueella. Norjan puolella sijaitsema Näätämön kylä (kartta 1) oli 1800-lu- vun alussa lähes täysin kolttasaamelainen, mutta tilanne muuttui nopeasti suomalaisten muuton myötä. (Lähteenmäki, 2004, s. 393395; Wikan, 1995, s. 99-102, 109-125.) 


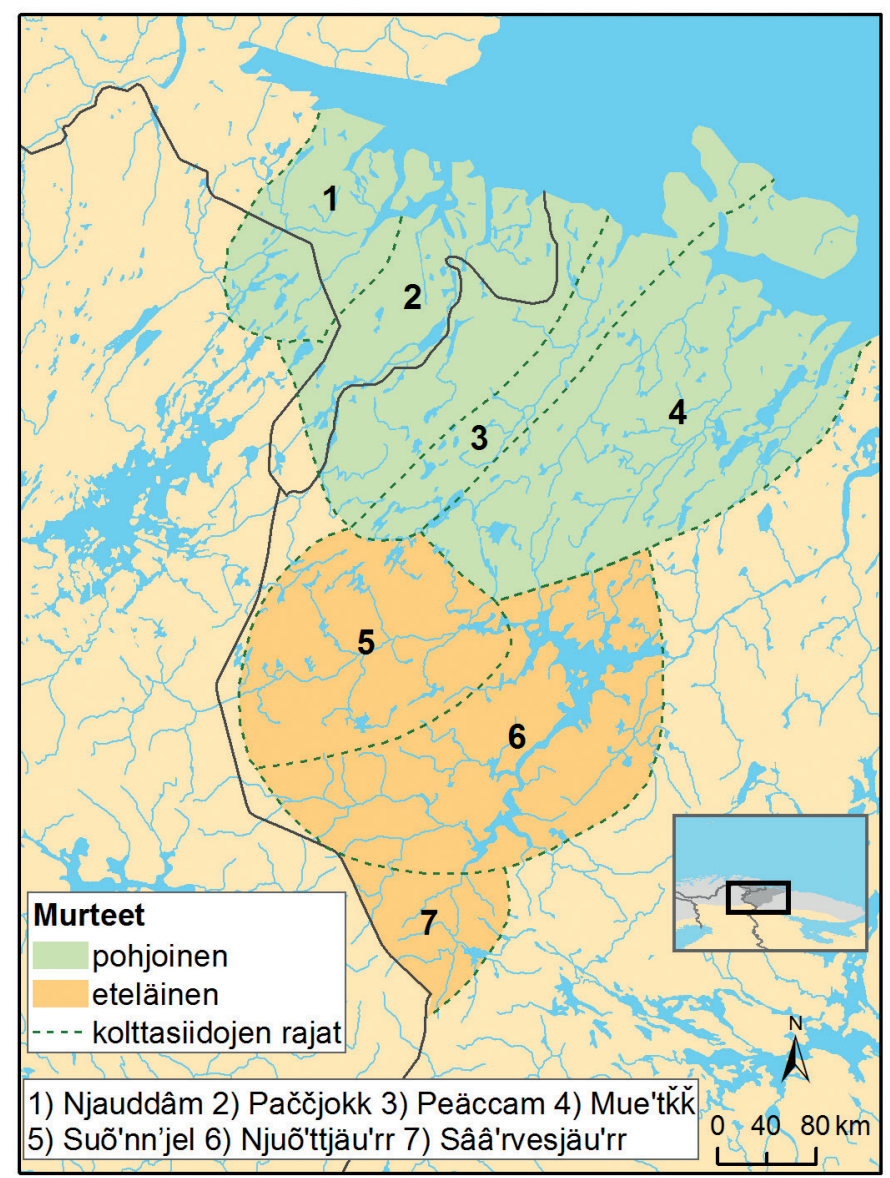

Kartta 1 Kolttasaamelaiset siidat.

Timo Rantanen. Pohjautuu (Pennanen \& Näkkäläjärvi, 2000, s. 159).

Taulukko 2. Näätämön kylän väestöryhmien määrä väestönlaskun mukaan (Wikan, 1995, s. 189)

\begin{tabular}{|c|c|c|c|c|c|c|c|c|c|c|c|}
\hline & \multicolumn{2}{|c|}{\begin{tabular}{|l} 
Koltta- \\
saamelaiset
\end{tabular}} & \multicolumn{2}{|c|}{$\begin{array}{l}\text { Meri- } \\
\text { saamelaiset }\end{array}$} & \multicolumn{2}{|c|}{ Suomalaiset } & \multicolumn{2}{|c|}{ Karjalaiset } & \multicolumn{2}{|c|}{ Norjalaiset } & \multirow[t]{2}{*}{ Yht. } \\
\hline & & $\%$ & & $\%$ & & $\%$ & & $\%$ & & $\%$ & \\
\hline 1845 & 28 & 38,4 & & & 45 & 61,6 & & & & & 73 \\
\hline 1855 & 24 & 25,3 & & & 71 & 74,7 & & & & & 95 \\
\hline 1865 & 12 & 9,6 & & & 92 & 88,4 & & & & & 104 \\
\hline 1875 & 17 & 10,1 & 5 & 2,9 & 147 & 87,0 & & & & & 169 \\
\hline 1885 & 20 & 9,3 & 9 & 4,2 & 173 & 80,5 & 13 & 6,0 & & & 215 \\
\hline 1891 & 21 & 9,7 & 7 & 3,2 & 179 & 82,5 & 8 & 3,7 & 2 & 0,7 & 217 \\
\hline 1900 & 23 & 11,3 & 8 & 3,9 & 155 & 76,5 & 10 & 4,9 & 7 & 3,5 & 203 \\
\hline
\end{tabular}


Taulukosta 2. käy ilmi, että suomalaiset olivat enemmistönä Näätämön kylässä jo vuonna 1845 ja heidän määränsä moninkertaistui puolessa vuosisadassa. Kolttasaamelaisten suhteellinen määrä puolestaan väheni rajusti absoluuttisen määrän laskiessa vain hiukan.

Vaikka merisaamelaiset olivat suurin ihmisryhmä Etelä-Varangin rannikkoseudulla, heitä asui vain vähän Näätämön kylässä (Wikan, 1995, s. 186). Kolttasaamelaisten ja pohjoissaamelaisten väliset kontaktit tapahtuivat siis pääosin muualla Etelä-Varangin alueella ja ne liittyivät elinkeinojen harjoittamiseen. Väestöryhmien välillä ei ollut seka-avioliittoja, sillä ortodoksiset kolttasaamelaiset menivät naimisiin lähinnä toisten siidojen kolttasaamelaisten kanssa eivätkä luterilaisten merisaamelaisten tai suomalaisten kanssa (Wikan, 1995, s. 192, 198).

\section{AINEISTO}

Tämän artikkelin tutkimusaineistona käytän Eliel Lagercrantzin vuonna 1920 keräämiä tekstejä (1961), jotka hän keräsi kahdelta kolttasaamelaiselta informantilta. Aineisto on laajuudeltaan noin 32 sivua, sisältäen sekä suomalais-ugrilaisella tarkekirjoituksella kirjoitetut tekstit että niiden saksankieliset käännökset. Aineisto koostuu yhtä lyhyttä omakohtaista muistelmaa lukuun ottamatta puolesta sivusta kahdeksaan sivuun pitkistä folkloreteksteistä. Lagercrantz keräsi samoilta informanteilta myös Näätämön murteen sanastoa saamelaiskielten sanakirjaansa varten (Lagercrantz, 1939).

Oskar Romanoff (1878-1943), jota kutsuttiin suomeksi myös Savan Oskiksi isänsä Savan mukaan, oli yksi harvoista Näätämön kolttasaamelaisista, jotka kävivät koulua ennen kuin Näätämön koulu avattiin. Hän kävi venäläistä luostarikoulua, jota pidettiin Paatsjoen kirkon Boris Glebin yhteydessä.
Koulussa hän oppi useita kieliä mm. venäjää, jota osasi myös kirjoittaa. On oletettavaa, että koulua käydessään hän tutustui myös muiden siidojen kolttasaamelaisiin, mikä puolestaan tuki hänen koltansaamen kielitaitoaan. Romanoff oli ammatiltaan poronhoitaja, mutta toimi 1920-luvulla myös kirkonvanhimpana sekä Näätämön kolttasaamelaisten viimeisenä luottamusmiehenä eli kylänvanhimpana. (Lagercrantz, 1961, 172; Wikan, 1995, s. 198, 267.) Romanoffin käyttämää kieltä Lagercrantz kuvailee koltansaamen ja merisaamen sekamurteeksi (Lagercrantz, 1939, s. 1205). Lagercrantz keräsi Romanoffilta yhden sadun merisaameksi, kaksi koltansaameksi ja lisäksi Näätämön murteen sanastoa.

Toinen Näätämön kolttasaamelainen, jolta Lagercrantz keräsi tekstejä, oli Ondrei- tai Onteri-niminen mies. Lagercrantz ei mainitse hänen sukunimeään, mutta hän oli todennäköisesti Ondre Jakobovitsj Lietoff (n. 1856-1927), joka oli Oskarin serkku. Koska hänen isänsä Jakob Romanovitsj Lietoff (1833-1867) kuoli Ondrein ollessa pieni, Ondrein kasvatti hänen isoisänsä Roman Feodorovitsj Lietoff (s. n. 1795, k. vuosien 1865 ja 1875 välissä). Nuorena Ondrei oli renkinä Oskarin perheessä, ja myöhemmin työskenteli ainakin poronhoitajana, kalastajana sekä halonhakkaajana. Hänen vaimonsa Katharina Vasiliedatter Karpvask, joka syntyi noin vuonna 1857, oli kotoisin Paatsjoelta ja oli mahdollisesti venäläisen kauppiaan tytär (Wikan, 1995, s. 196-197, liite 1.), tosin hänen täytyi olla ainakin koltansaamentaitoinen, sillä Lagercrantz keräsi murteen sanastoa myös häneltä. Lagercrantz keräsi Ondreilta sekä satuja että Näätämön murteen sanastoa. Hän kuvailee Ondrein kieltä koltansaamen ja merisaamen sekamurteeksi, mutta kykeneväksi tarvittaessa esittämään samat sananmuodot molemmilla kielillä, mikä viittaa hänen kykyynsä erottaa lähisukuisia kieliä toisistaan. (Lagercrantz, 1939, s. 1205; 1961, 
s. 187-188) Koska Ondrein sukunimestä ei ole varmuutta, kutsun tässä artikkelissa Lagercrantzin informantteja heidän etunimillään Oskariksi ja Ondreiksi.

Kaikkien muiden Näätämöstä kerättyjen koltansaamen aineistojen perusteella Oskarin ja Ondrein idiolektit vaikuttavat edustavan tyypillistä Näätämössä puhuttua koltansaamea. J. A. Friis oli tiettävästi ensimmäinen, joka keräsi aineistoa Näätämön murteesta ja Lagercrantzin lisäksi toistaiseksi ainoa, jonka aineistot on julkaistu. Friis kuvailee keräämänsä sadun (Friis, 1856, s. 108-112) kieltä koltansaamen ja merisaamen sekakieleksi (Friis, 1856, s. II). Friisin ja Lagercrantzin lisäksi Näätämön murretta on tallentanut vain Mikko Korhonen, joka nauhoitti Näätämön murteen viimeisenä puhujana pidetyn Jogar Mikkelsen Ivanowitzin puhetta noin neljä tuntia vuonna 1964. Nauhoituksia säilytetään Oulun yliopiston Saamelaisessa kulttuuriarkistossa. Myös Jogarin idiolektia voi pitää vahvasti merisaamen vaikutteisena.

Tekstien kieleen on syytä suhtautua kriittisesti. 1900-luvun alussa tutkijoilla ei ollut käytössä äänitystekniikkaa, vaan kielenainekset kirjattiin paperille suoraan puheesta, mistä johtuen aineisto saattaa sisältää virheitä, erityisesti, koska koltansaame oli Lagercrantzille vieras kieli, jota hän keräsi vain muutamia viikkoja. Vaikka ajan hengen mukaisesti kielenainekset pyrittiin kirjoittamaan muistiin mahdollisimman tarkasti erityisesti äänne- ja muoto-opin osalta, Lagercrantz mitä todennäköisemmin muokkasi aineistoa jonkin verran. Aineistosta on todennäköisesti poistettu ainakin kesken jääneitä sanoja sekä luultavasti myös suomen kielen vaikutusta, jota teksteissä ei esiinny ollenkaan. Suomalaiset olivat Näätämön alueella reilusti suurin väestöryhmä, ja myös kolttasaamelaiset puhuivat hyvin kolttaa, mihin viittaa myös se, että Lagercrantzin (1950, s. 131) mukaan Näätämön saamelaiset olivat suomalaistumassa.

\section{METODOLOGIA JA TEORIATAUSTA}

Monikielisen yhteisön jäsenet saattavat yhdistellä osaamiaan kieliä eri tavoin riippuen kielenkäyttötilanteesta ja tilanteeseen osallistuvien kielitaidosta. Puhujat voivat vaihdella puhetapaansa tilanteen mukaan ja kieliyhteisön puhujien kielelliset repertuaarit voivat erota toisistaan. Esimerkiksi Sarhimaa (1999, s. 231-251) on osoittanut, että hänen tutkimassaan karjalais-venäläisessä-suomalaisessa kielikontaktitilanteessa kaikkien puhujien kielelliseen repertuaariin kuuluu kahdesta kuuteen erilaista karjalaa ja venäjää tai karjalaa ja suomea yhdistelevää koodia. Puhuja saattaa käyttää yhdessä tilanteessa sellaista karjalaa, jossa venäjän vaikutus on pieni, ja toisessa tilanteessa taas sellaista karjalaa, jossa venäjän vaikutus on huomattavasti suurempi. Toisin kuin Sarhimaa (1999), kutsun tässä artikkelissa erilaisia kielenkäyttötapoja erillisiksi rekistereiksi enkä koodeiksi. Rekisterillä tarkoitan puhujan tilanteessa käyttämää kielenkäyttötapaa, joka sisältää myös siinä mahdollisesti ilmenevän koodinsekoituksen.

Yleisin termi, jolla tutkimuskirjallisuudessa käytetään kahden kielen esiintymisestä samassa tilanteessa, on koodinvaibto (codeswitching). Sen lisäksi käytetään myös useita muita termejä, kuten koodin kopiointi (codecopying) (Johansson, 1998). Terminologian ja tutkimuksen metodologian kirjavuuteen on vaikuttanut muun muassa se, että koodinvaihtoa on tutkittu, mm. psykolingvistiikan, sosiolingvistiikan ja keskusteluntutkimuksen näkökulmista (Kovács, 2009, s. 24, 45).

Tässä artikkelissa nojaudun Muyskenin (2000) kehittämään koodinsekoitusmalliin. Syynä on se, että käyttämäni tutkimusaineiston teksteissä koltansaame ja merisaame yhdistyvät eri tavoin. Osasta teks- 
teistä voi selvästi määritellä pääkieleksi joko koltansaamen tai merisaamen, mutta osasta on mahdotonta sanoa, kumpi kielistä toimii pääkielenä. Mielestäni Myuskenin koodinsekoitusmalli soveltuu parhaiten tällaisen aineiston analysointiin. Käytän Muyskenin (2000, s. 1, 4) tavoin termiä koodinsekoitus (code-mixing) yleisellä tasolla kuvaamaan tilannetta, jossa kahden kielen sanastoa ja kielioppia esiintyy samassa kielenkäyttötilanteessa. Muyskenin mukaan termi koodinvaihto (code-switching) soveltuu vain sellaisiin tilanteisiin, joissa eri kielten ainekset seuraavat toisiaan vaikuttamatta toistensa kielioppiin (koodien vuorottelu). Muysken (2000, s. 8-9) jakaa koodinsekoituksen kolmeen osaan: koodinupotuksiin (insertion) koodien vuorotteluun (alternation) sekä kongruenttiin leksikalisaatioon (congruent lexicalization). Näistä tutkimusaineistossani esiintyy koodinupotuksia sekä kongruenttia leksikalisaatiota mutta ei koodien vuorottelua, joka tarkoittaa tilannetta, jossa eri kielistä peräisin olevat ainekset seuraavat toisiaan vaikuttamatta toistensa kielioppeihin. Tällaiset vaihdot asettuvat tavallisesti lauseke- tai lauserajoille.

Koodinupotuksissa lauseen matriisikielen eli pääkielen A määrittämään lausekehykseen upotetaan toisen kielen B aineksia, jotka ovat yleensä sanan tai lausekkeen mittaisia (Myusken, 2000, s. 60-95). Koodinupotukset vastaavat Myers-Scottonin (1993) matriisikielimallissa (matrix language frame model) upotettuja kielisaarekkeita. Kuten monet koodinvaihtotutkijat, pidän koodinupotuksia ja lainasanoja jatkumona. Tässä artikkelissa analyysin kannalta on kuitenkin tärkeää vetää raja niiden välille. Erotan ne toisistaan sanojen levikkien sekä niiden sisältämien äänteellisten ja morfologisten piirteiden perusteella. Mikäli sana on attestoitu vain yhdestä kielestä, pidän sitä siihen kieleen kuuluvana sanana, ellei sen fonologia ja/tai morfologia viittaa muuhun. Mikäli sanan levikki kattaa molemmat kielet, pidän sanaa siihen kieleen kuuluvana, johon sen fonologia ja/tai morfologia ensisijaisesti viittaavat.

Kongruentti leksikalisaatio tarkoittaa tilannetta, jossa kielille yhteiset kieliopilliset rakenteet täytetään eri kielistä peräisin olevilla kieliopillisilla aineksilla sekä sanastolla. Sen edellytyksenä on, että kontaktoivien kielten kieliopilliset rakenteet vastaavat tarpeeksi suuressa määrin toisiaan, esimerkiksi sanajärjestyksen ja konstruktioiden osalta (Myusken, 2000, s. 122-153). Tällaisessa tilanteessa puheen pääkielen määrittäminen on vaikeaa tai lähes mahdotonta. Esimerkiksi Turusen (1997) mukaan nykyvatjalaisten puheesta on vaikea sanoa, mikä kieli toimii pääkielenä, sillä vatjalaiset käyttävät puheessaan sekaisin vatjaa, inkeroista, viroa, suomea sekä venäjää. Myös kielenpuhujat itse saattavat huomata tämän.

Minul kaik mèb / kerra viron kieli, suomen kieli [naurabtaa] vadja kieli kaik mennē sekasi / kaik mēb. 'Minulla kaikki menee / kerran viron kieli, suomen kieli, vatjan kieli, kaikki menee sekaisin / sekaisin kaikki menee.' (Turunen, 1997, s. 215)

Kongruentti leksikalisaatio esiintyy usein murteen ja yleiskielen tai lähisukukielten välisissä kontakteissa, esim. suomen ja viron välillä (esim. Frick, Grünthal \& Praakli, 2018), sillä ne ovat typologisesti riittävän läheisiä ja niillä on tarpeeksi paljon yhteisiä kieliopillisia rakenteita. Typologisesti läheisiä kielimuotoja ovat myös koltansaame ja merisaame, jotka vastaavat pitkälti toisiaan morfologian ja lauseopin tasolla (Miestamo, 2011, s. 140-142). Lähisukukielten lisäksi kongruentti leksikalisaatio voi esiintyä myös typologisesti erilaisten kielten, esimerkiksi venäjän ja ersän kontaktissa (Janurik, 2017), jos kielillä on yhteisiä kieliopillisia konstruktioita. Kongruentti leksikalisaatio voi sisältää myös sanansisäisiä vaihtoja, joita kutsun tässä 
artikkelissa äänteellisiksi sekä kieliopillisiksi hybridimuodoiksi. Tällaisia muotoja esiintyy esimerkiksi hollannin ja friisin välisessä kontaktitilanteessa (Myusken, 2000, s. 137).

\section{KOODIEN SEKOITTUMINEN AINEISTOSSA}

Tässä luvussa esittelen aineistossa esiintyvää koodien sekoittumista. Olen mahdollisuuksien mukaan kirjoittanut kuhunkin kieleen kuuluvat sanat kyseisen kielen nykyortografialla. Merkitsen merisaamen lihavoinnilla, koltansaamen kursivoinnilla ja hybridimuodot näiden $y$ hdistelmällä. Kirjakielen normeista poiketen olen kirjoittanut sanat murteiden mukaisessa muodossa käsitellessäni hybridimuotoja sekä käsitellessäni koodien sekoittumista, mikäli se on analyysin kannalta tarpeen. Koska merisaame ja koltansaame ovat lähisukukieliä ja niiden sanasto, äänneoppi ja muoto-oppi ovat lähellä toisiaan, on toisinaan vaikea sanoa, kumpaan kieleen jokin sananmuoto kuuluu. Osa sanoista on täysin homonyymejä (esim. pronominit mon 1sG, sij 3PL sekä leäk olla.KON) ja osa niin lähellä toisiaan, että niitä on vaikea erottaa (esim. koltansaamen $p a ̈$ 'rnn 'poika', muorrl' 'puu' vs. merisaame bárnni, muorra). Tällaiset sanat olen kirjoittanut koltansaamen nykyortografian mukaisesti ilman kursivointia tai alleviivausta. Aineiston analyysissa olen ottanut huomioon sekä alueella puhutun merisaamen (Lagercrantz, 1929) että Näätämön murteen erityispiirteet. Mikäli aineisto analysoidaan vain muiden koltansaamen murteiden perusteella, aineisto näyttää merisaamelaisemmalta kuin se todellisuudessa onkaan, sillä Näätämön murre jakaa merisaamen kanssa tiettyjä äänne- ja muoto-opillisia piirteitä, jotka erottavat sen muista koltansaamen murteista. Esimerkiksi Näätämön murteessa geminaatta

1 kirjakielessä muõrr jj on klusiliutunut, esim. ledje ${ }^{2}$ [led'd'e] olla. PTR.3PL (Lagercrantz, 1961, s. 187), mutta muissa koltansaamen murteissa se on säilynyt puolivokaalina ( $\left.l e^{\prime} j j e\right)$. Tämä pohjoissaamesta levinnyt fonotaktinen piirre esiintyy Näätämön murteessa säännöllisenä.

\subsection{Koodien sekoittuminen Oskarin teksteissä}

Kuten aineiston esittelyssä totesin, Lagercrantz tallensi Oskarilta yhden tekstin merisaameksi ja kaksi tekstiä koltansaameksi. Hänen merisaamen tekstinsä sisältää vain yksittäisiä koodinupotuksia, joissa merisaamen lauseeseen on upotettu jokin koltansaamen sana. Tavallisin tapaus on partikkeli še 'myös' (1). Lagercrantzin (1961, s. 31) tosin huomauttaa, että se on levinnyt koltansaamesta myös Etelä-Varangissa puhuttuun merisaameen. Se ei kuitenkaan ole kielessä yleinen eikä esiinny esimerkiksi Lagercrantzin (1939) saamelaiskielten laajassa sanakirjassa. Tästä syystä sanaa voinee pitää koodinupotuksena koltansaamesta. Selviä koodinupotuksia ovat sananmuodot, joissa etuvokaalin edellä esiintyy palataaliklusiili, kuten esimerkissä2. Muissa koltansaamen murteissa useimmat klusiilit ovat palataalistuneita, kun niitä seuraa tai varhaisemmassa kielen vaiheessa seurasi etuvokaali (ks. tarkemmin Feist, 2015, s. 46-49), mutta Näätämön murteessa tämä piirre esiintyy vain sporadisesti, esim. Ke.Esse 'kesä' (Lagercrantz, 1939, \$2294), Kе́ $\varepsilon \cdot \delta^{e} \mathrm{Ke}$ 'kivi' (Lagercrantz, 1939, \$2237) vrt. Suonikylä ̌̌ie'ss, ̌̌eä'dğğ. Joko tämä fonotaktinen piirre ei ole ollut koskaan säännöllinen Näätämön murteessa tai se on alkanut hävitä merisaamen kontaktivaikutuksesta, sillä merisaamessa konsonantit eivät ole palataalistuneita tässä asemassa.

2 Kirjoitan tässä artikkelissa klusiiliutuneen geminaatta $j j$ :n $d j$. Konventio on otettu pohjoissaamen nykyortografiasta. 


$\begin{array}{llll}\text { (1) Dat } & \text { válde } & \text { ja } & \text { luite } \\ \text { ne } & \text { ottaa.PRT.3PL } & \text { ja } & \text { laskea.PRT.3PL } \\ \text { dan } & \text { nieidda } & \text { śe } & \text { ráigái. } \\ \text { se.AKK } & \text { tyttö.AKK } & \text { myös } & \text { reikä.ILL }\end{array}$

'Ne ottivat ja laskivat myös sen tytön kuoppaan.' (Lagercrantz, 1961, s. 180)

(2) seämma sunnje $\check{\text { iâavi. }}$

sama 3sG.ILL käydä.PRT.3sG

'Hänelle kävi samoin.' (Lagercrantz, 1961, s. 175)

Oskarin koltansaamen teksteissä esiintyy melko paljon koodinupotuksia merisaamesta. Upotukset ovat pääsääntöisesti yhden sanan tai lausekkeen mittaisia. Esimerkissä 3 lähtökohtaisesti koltansaamenkieliseen lauseeseen on upotettu merisaamen finiittiverbi sekä postpositiolauseke. Esimerkissä 4 esiintyy koltansaamenkieliseen lauseeseen upotettu merisaamen verbilauseke sekä hybridimuotoinen demonstratiivipronomini $t a z$, jossa koltansaameen viittaa soinnillinen sibilantti (tốzzz), ja merisaameen vokaalin laatu (dasa).

$\begin{array}{llllll}\text { (3) } \mathrm{De} & \text { son } & \text { kooll } & \text { ooumaž } & \text { puó'di } & \text { suu } \\ \text { sitten } & \text { 3sG } & \text { kuulla.3sG } & \text { mies } & \text { tulla.3sG } & 3 \mathrm{sG} \\ \text { luuzz } & \text { ja } & \text { dajai: } & \text { mâi'd } & \text { åårak } & \text { ton } \\ \text { luokse } & \text { ja } & \text { kuulla.3sG } & \text { mikä.AKK } & \text { tehdä.2sG } & 2 \mathrm{sG} \\ \text { tä'st? } & \text { Koozz } & \text { son } & \text { šâdd } & \text { čalmmiid } & \text { haga? } \\ \text { tämä.3sG } & \text { mikä.ILL } & \text { 3sG } & \text { joutua.3sG } & \text { silmä.PL.GEN } & \text { ilman }\end{array}$

'Sitten hän kuulee, (että) mies tuli hänen luokseen ja sanoi: Mitä teet tässä? [toinen vastaa:]

Minne hän joutuu ilman silmiä?' (Lagercrantz, 1961, s. 183)

(4) De

sitten

boahtegodi.

tulla.INK.PRT.3sG

tôn

se.AKK

$\underline{\text { taz }}$

se.ILL joo'di nu

kulkea.3sg niin

$\mathrm{Ja}$

ja

stuôrr muôr

suuri.ATTR

ja

ja $k u \prime^{\prime} \check{k}^{\prime}$, go

kauan kun

son kaauni

3sG löytä.̈.PRT.3sG

ja kuäryai

ja kiivetä.PRT.3sG

puu.AKK ja

blauvslỗoi

siunata.PRT.3SG seavdnjat

pimeä

jiijjâz.

REFL.3SG.AKK

'Sitten kulki niin kauan, että alkoi tulla pimeä. Ja hän löysi sen suuren puun ja kiipesi siihen ja siunasi itsensä.' (Lagercrantz, 1961, s. 183)

Kovács ja Janurik (2018, s. 47-49) ovat kiinnittäneet huomiota siihen, että monissa kielikontaktitilanteissa kymmentä suurempien numeraalien yhteydessä esiintyy koodinupotuksia enemmistökielestä. Tällainen ten- denssi esiintyy niin englannin kanssa kontaktissa olevassa suomessa (esim. Kovács, 2001, s. 199) kuin monissa venäjän kanssa kontaktissa olevissa suomalais-ugrilaisissa vähemmistökielissä, kuten ersässä (Janurik, 2017, 
s. 116-122), karjalassa (Sarhimaa, 1999, s. 234) sekä kiltinänsaamessa (Pineda, 2008, s. 50-52). Ilmiötä on selitetty kouluopetuksella, sillä esimerkiksi matematiikkaa opetetaan monilla alueilla ainoastaan enemmistökielellä (esim. Janurik, 2017, s. 199; Sarhimaa, 1999, s. 234).

Vaikka tutkimusaineistossani esiintyy pieniä numeraaleja, jotka ovat selvästi koltansaamea, esim. ôhtt 'yksi' (Lagercrantz, 1961, s. 182) ja kue'btt 'kaksi' (Lagercrantz, 1961, s. 183), kaikki Oskarin koltansaamen teksteissä esiintyvät moniosaiset numeraalit ovat merisaameksi, kuten esimerkkilauseessa 5, vrt. koltansaame ótmlo. Osassa tapauksista numeraalien alkuosaa on vaikea tunnistaa, mahdollisesti pikapuhunnasta johtuvan väärinkirjauksen takia, näin on esimerkkilauseessa 6, vrt. merisaamen genetiivimuodot oktanuppelogi, guoktenuppelogi; koltansaame ôtmlo, kuâtmlo. Myös ainoa Ondrein koltansaame-merisaame-rekisterissä esiintyvä moniosainen numeraali čiežalogi 'seitsemänkymmentä' (Lagercrantz, 1961, s. 200) sekä suurin osa yksiosaisista numeraaleista on merisaameksi. Merisaamen numeraalien esiintymistä koltansaamen koodin sisällä ei voida selittää kouluopetuksella, sillä sellaista ei ollut 1900-luvun alussa merisaameksi. Todennäköisenä syynä niiden esiintymiselle pidän sitä, että merisaamelaisia asui Etelä-Varangin alueella kymmeniä kertoja enemmän kuin kolttasaamelaisia, mikä pakotti myös kolttasaamelaisten käyttämään merisaamen numeraaleja esimerkiksi harjoittaessa kauppaa sekä kalastaessa yhdessä merisaamelaisten kanssa, sillä koltansaamen numeraalit ovat lähes tunnistamattomia merisaamelaisille voimakkaan sisä- ja loppuheittoisuuden takia, esim. merisaame oktanuppelot vs. koltansaame ôtmlo.

(5) teäčča gâlgg ga $^{3} \quad$ puä'tted

kanttori.geN täytyä.3sg tulla

beal ovtnuplogi äi'ğğ

puoli yksitoista.GeN aika

'Kanttorin täytyy tulla puoli yhdentoista aikaan.' (Lagercrantz, 1961, s. 185)

(6)

\begin{tabular}{|c|c|c|c|c|}
\hline $\begin{array}{l}\text { paapp } \\
\text { pappi.GEN }\end{array}$ & $\begin{array}{l}\text { kaav } \\
\text { vaimo.GEN }\end{array}$ & $\begin{array}{l}\text { gâlgg } \\
\text { täytyä.GEN }\end{array}$ & $\begin{array}{l}\text { puä'tted } \\
\text { tulla }\end{array}$ & $\begin{array}{l}\text { ađnuplogi } \\
\text { yksitoista.GEN }\end{array}$ \\
\hline "̈äi'ğ, & teäč́ak & kaav & & \\
\hline a.GEN & kanttori.GEN & vaimo.GEN & & \\
\hline 1 & kuatnuplogi & & äi'ğğg. & \\
\hline & yksitoista.GEN & & & \\
\hline
\end{tabular}

'Papin vaimon täytyy tulla yhdentoista aikaan, kanttorin vaimon puoli kahdentoista aikaan.' (Lagercrantz, 1961, s. 185)

3 Verbi esiintyy koltansaamen kirjakielessä klusiilialukkeettomana ôlggâd, mutta koltansaamen pohjoismurteissa (gõlggâd) ja merisaamessa (galgat) klusiilialukkeellisena. 
Kovács ja Janurik (2018, s. 49) huomauttavat että, tilanteessa, jossa käytetään ainoastaan enemmistökielen numeraaleja, on syytä pohtia, onko kyseessä ennemmin numeraalien lainaaminen kuin koodinupotus. Vaikka numeraalien lainaaminen on huomattavasti harvinaisempaa kuin esimerkiksi substantiivien tai verbien, maailman kielten joukossa on useita tapauksia, joissa myös numeraaleja on lainattu (Matras, 2009, s. 201-203). Lainaaminen voi olla tulla kyseeseen myös tässä tapauksessa, mutta täytyy ottaa huomioon, että käyttämäni aineisto on suppea ja sisältää vain muutamia tapauksia, joissa esiintyy kymmentä suurempi numeraali.

\subsection{Koodien sekoittuminen Ondrein teksteissä}

Lagercrantzin mukaan Ondrein tekstit ovat koltansaamen ja merisaamen sekakieltä, mutta tarkempi tarkastelu osoittaa, että osa teksteistä (Lagercrantz, 1961 s. 188-194, 202-203) on merisaamea, joka sisältää vain yksittäisiä yhden sanan mittaisia koodinupotuksia koltansaamesta. Koodinupotukset ovat lähinnä yksittäisiä verbimuotoja sellaisista verbeistä, jotka ovat yhteisiä koltansaamelle ja merisaamelle. Tällaisia ovat esimerkiksi esimerkkilauseen 7 puó'di, merisaame (bođii), sekä esimerkkilauseen 8 piâzzi, merisaame (beasai). Nähdäkseni nämä eivät aiheuttaneet kommunikaatio-ongelmia merisaamen puhujien kanssa muotojen läheisyyden vuoksi. Nomineja sisältävät koodinupotukset ovat harvinaisempia. Esimerkkilauseessa 9 esiintyy koltansaamen nominista jokk yksikön illatiivimuoto jokke. Vaikka sanassa ei ole koltansaamelle tyypillistä toisen tavun etisestä vokaalista $e$ johtuvaa suprasegmentaalista palatalisaatiota (vrt.jo'ǩke) sanan osoittaa koltansaameksi yksikön illatiivin pääte -e, jota vastaava sijapääte merisaamessa on -ii (jobkii).

$\begin{array}{llll}\text { (7) } \text { Okta } & \text { stállu } & \text { puõ'di } & \text { Vearas } \\ \text { yksi } & \text { staalo } & \text { tulla.PRT.3sG } & \text { Vesisaari.LOK } \\ \text { rastá } & \text { Givjui. } & & \\ \text { yli } & \text { Givju.ILL } & & \end{array}$

'Yksi staalo tuli Vesisaaresta [meren] yli Givjun saarelle.' (Lagercrantz, 1961, s. 188)

(8) Muhto gánda piâzzi deike.

mutta poika päästä.PRT.3sG tänne

'Mutta poika pääsi tänne.' (Lagercrantz, 1961, s. 190)

(9) go

kun

časkkii

lyödä.PRT.3sG

jokke

joki.ILL

manaiga.

skirvehedje,

kurvata.PRT.3PL

'Kun he kurvasivat, [poika] löi keihässauvalla [staalon] jalan poikki. [Sitten pojat] menivät jokeen.' (Lagercrantz, 1961, s. 194)

\section{sáitisoppiin}

keihässauva.coM

rastá.

jalka.AKK poikki 
Suuri osa Ondrein teksteistä on sellaisia, joista ei voi sanoa, mikä kieli toimii niiden pääkielenä. Niissä koodi vaihtuu jatkuvasti merisaamen ja koltansaamen välillä, kuten esimerkeissä 10 ja 11 . Niitä voi pitää Myuskenin (2000) koodinsekoitusmallin mukaan kongruenttina leksikalisaationa, jossa kielenpuhuja täyttää kielten yhteiset rakenteet eri kielten sanastolla ja kieliopillisilla aineksilla. Koltansaamen ja merisaamen välillä ei ole osoitettavissa roolinjakoa, esimerkiksi niin, että yhdestä kielestä olisi peräisin verbintaivutus ja toisesta nominitaivutus, vaan sekä kielioppia että sanastoa on peräisin molemmista kielistä.

\begin{tabular}{|c|c|c|c|c|}
\hline (10) De & son & golbma & háve & jeli \\
\hline sitten & $3 S G$ & kolme & kerta.AKK & käydä.PRT.3sG \\
\hline kióčćmen, & & mut & $\mathrm{ij}$ & vuäinnam \\
\hline katsoa.AKT & & mutta & NEG.3SG & nähdä.PARTIS.PRT \\
\hline ij & maidege. & Mihkkalin & celkki: & mon \\
\hline NEG.3SG & mitään & Mihkali.ком & sanoa.PRT.3sG & $1 S G$ \\
\hline ihtten & áiggum & vue'lğğed $^{4}$ & jâdda & \\
\hline huomenna & aikoa.1sG & lähteä & huomenna & \\
\hline áiggum & vue'lğğed & mååust & (ruoktot). & \\
\hline aikoa.1sG & lähteä & takaisin & takaisin & \\
\hline
\end{tabular}

'Sitten hän kolme kertaa kävi katsomassa, mutta ei nähnyt mitään. Mihkalille sanoi: Minä huomenna aion lähteä, huomenna aion lähteä takaisin (takaisin).' (Lagercrantz, 1961, s. 199)

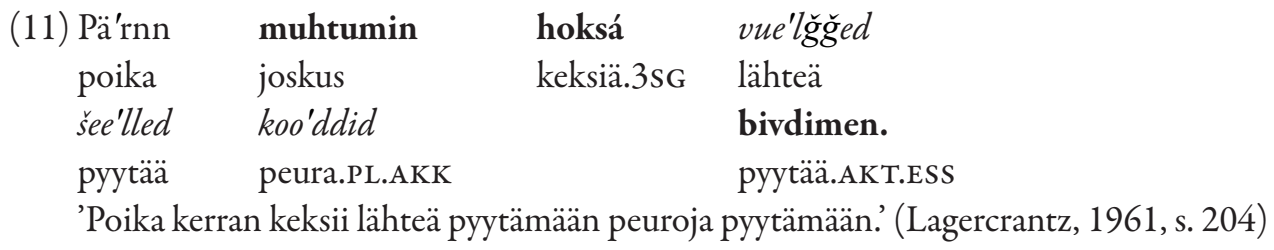

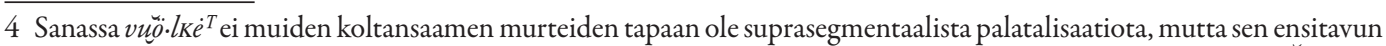

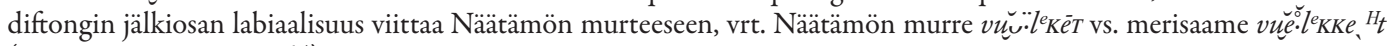
(Lagercrantz, 1939, \$8764).

Esimerkki 10 sisältää äänteellisen hybridimuodon jeli, joka sisältää äännepiirteitä molemmista kielistä. Sanassa esiintyy koltansaamen mukaisesti j-proteesi, joka esiintyy alkuperäisen ${ }^{*} \bar{\varepsilon}$ edellä, sekä merisaamen mukainen diftongin oikeneminen eallit'elää, käydä’ elii'eli, kävi' (äänteellisistä hybridimuodoista ks. tarkemmin luku 6.1). Turusen (1997, s. 215) vatjalaisinformantin tavoin Ondrei vaikuttaa olevan tietoinen kaksikielisestä kerronnastaan. Tähän viittaa se, että hän korjaa omaa puhettaan: ihtten áiggum vue'lğğed, jâdđa áiggum vue'lğğed. Oletan, ettei esimerkkilauseen 10 sulkujen sisään kirjoitettu ruoktot 'takaisin' kuulu kerrontaan, vaan Ondrei käänsi samaa merkitsevän koltansaamen sanan mååust Lagercrantzin pyynnöstä merisaameksi. Myös esimerkkilauseet 12 ja 13 sisältävät jatkuvia vaihtoja koltansaamen ja merisaamen välillä. 
(12)

\begin{tabular}{|c|c|c|c|c|c|}
\hline $\mathrm{De}$ & son & \multicolumn{2}{|l|}{ pääjjai } & nuppi & vuoru. \\
\hline sitten & $3 S G$ & \multicolumn{2}{|c|}{ ampua.PRT.3sG } & toinen & kerta.AKK \\
\hline Eai & võl & \multicolumn{2}{|l|}{ vuâlggam, } & $\hat{a}^{\prime} l d d l a$ & \\
\hline NEG.3PL & vielä & \multicolumn{2}{|c|}{ lähteä.PARTIS.PRT } & lähelle.комР & \\
\hline tie'rre. & & De & son & jurddašii, & \\
\hline laukata.PRT.3PL & & sitten & $3 S G$ & ajatella.PRT.3sG & \\
\hline et & bákti & $\check{s a ̈ a ̈ j j . ~}$ & [kappaleraja] & & Son \\
\hline että & kallio & kaikua.3sG & & & $3 s G$ \\
\hline pääjjai & & kuälmad & vuoru. & Goddit & \\
\hline ampua.PRT.3sG & & kolme.ORD & kerta.AKK & peura.PL & \\
\hline . & jäämmam, & & aldelabbui & tie'rre. & \\
\hline EG.3PL & kuolla.PART & PRT & lähelle.кOMP & laukata.PRT.3sG & \\
\hline
\end{tabular}

'Sitten hän ampui toisen kerran (peuroja). Eivät vielä lähteneet, lähemmäs laukkasivat. Sitten hän ajatteli, että kallio kaikuu. Hän ampui kolmannen kerran. Peurat eivät kuolleet, lähemmäs laukkasivat.' (Lagercrantz, 1961, s. 204)

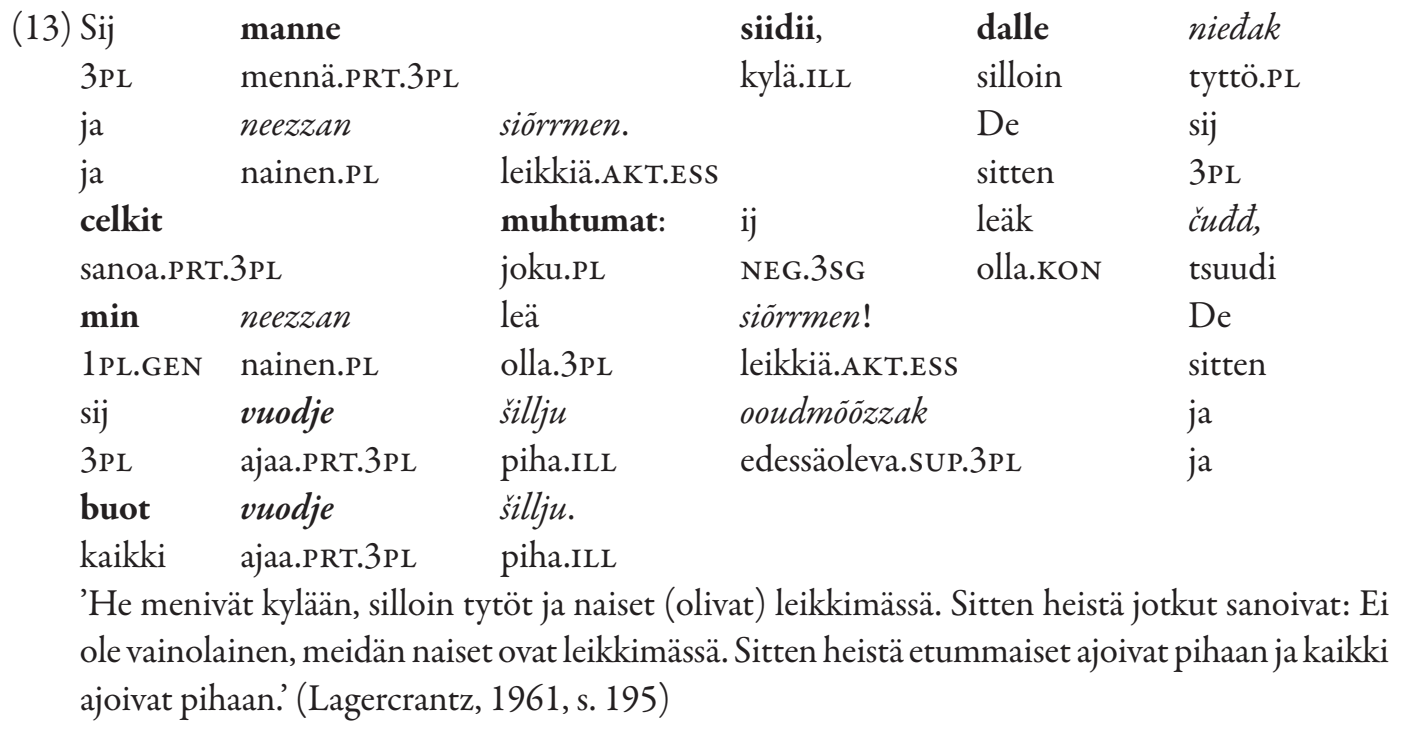

Esimerkki 12 sisältää kaksi kertaa adverbin lähemmäs. Näistä ensimmäinen on koltansaamen mukainen muoto àltelà. Toinen adverbi àlTelà̉uj sisältää merisaamen komparatiivisuffiksin. Kyseistä kyseistä sanavartaloa ei kuitenkaan tavata tässä merkityksessä merisaamessa. Se täytyy siis analysoida kieliopilliseksi hybridimuodoksi (ks. lisää 6.2), jossa koltansaamen sanavartaloa on taivutettu merisaamen taivutusopin mukaan. Mahdol- lisena hybridimuotona voidaan pitää myös verbimuotoa vuodje, jossa on merisaamen monikon kolmannen persoonan preteritin tunnus -e (vudje), mutta ensitavun diftongi on oientumaton koltansaamen tavoin (vuejju).

Kuten esimerkki 13 osoittaa, merisaamen ja koltansaamen morfologiset ainekset vaikuttavat olevan Ondreilla vapaassa vaihtelussa. Tästä esimerkkeinä on sekä yksikön illatiivi että monikon nominatiivi. Muodossa siidii 
on merisaamen mukainen yksikön illatiivin pääte - $i$ ja šillju koltansaamen illatiivin pääte ${ }^{5}$. Sekä nieđak että neezzan ovat monikon nominatiiveja, joista ensimmäinen on päätteellinen ja jälkimmäinen päätteetön monikon nominatiivi. Näätämön murteessa monikon nominatiivin tunnus on pääsääntöisesti - $k$. Pääte on lainattu murteeseen merisaamesta (Sammallahti, 1998, s. 31), jossa monikon nominatiivi on säännöllisesti $k$-päätteinen. Muissa koltansaamen murteissa monikon nominatiivi on aina päätteetön. Päätteettömiä monikon nominatiiveja esiintyy harvinaisena myös Näätämön murteessa, kuten esimerkkilauseen 13 muodossa neezzan. Muodossa niedak koltansaameen viittaa keskuskonsonantiston heikossa asteessa esiintyvä dentaalispirantti $d$, jonka sijalla merisaamessa olisi konsonanttiyhtymä idd (nieiddak).

\subsection{Oskarin ja Ondrein tekstien rekisterit}

Sarhimaan (1999) karjalaisten informanttien tavoin myös Oskar ja Ondrei hallitsivat erilaisia rekistereitä, joissa eri kielten ainekset yhdistyvät eri tavoin. Aineiston perusteella vaikuttaa siltä, että nämä rekisterit ovat vakiintuneita Oskarin ja Ondrein kielellisiin repertuaareihin, mihin mielestäni viittaa se, ettei rekisteri vaihdu koskaan kesken tekstin. Valitettavasti Lagercrantzin ja informanttien työskentelystä ei ole säilynyt tietoa esimerkiksi siitä, pyysikö Lagercrantz informanttejaan esittämään satuja eri kielillä, vai mistä variaatio eri tekstien välillä johtuu.

Aineiston analyysin perusteella voidaan sanoa, että sekä Oskarilla että Ondreilla on kaksi toisistaan eroavaa rekisteriä. Oskarin teksteissä toisen rekisterin pääkieli on merisaame ja toisen koltansaame. Molemmissa rekistereissä on lyhyitä koodinupotuksia toi-

5 Näätämön murteessa kirjakielestä poiketen $-\hat{a}, \mathrm{ks}$. tarkemmin Sammallahti, 1998, s. 31. sesta kielestä. Lagercrantz piti Ondrein kieltä koltansaamen ja merisaamen sekakielenä, mutta tarkempi analyysi osoittaa, että hän käytti kahta eri rekisteriä: Merisaamea, joka sisältää yksisanaisia koodinupotuksia koltansaamesta, sekä rekisteriä, jota kutsun koltansaame-merisaame-rekisteriksi. Sitä voidaan pitää kongruenttina leksikalisaationa, sillä se sisältää jatkuvia vaihtoja kielten välillä niin, että sekä sanasto että kieliopilliset morfeemit voivat olla peräisin kummasta kielestä tahansa. Lisäksi se sisältää muita rekistereitä enemmän äänneopillisia sekä kieliopillisia hybridimuotoja (ks. tarkemmin kappale 5).

Kuten aineiston esittelyssä mainittiin, Oskar osasi saamelaiskielten lisäksi myös venäjää. Oskar ja Ondrei puhuivat luultavasti myös suomea, sillä heidän aikanaan suomalaiset olivat enemmistönä Näätämön kylässä, sekä mahdollisesti myös norjaa, jota tarvittiin kommunikoidessa virkamiesten, opettajien ja luterilaisen papin kanssa. Aineistossa ei esiinny merkkejä muista kielistä kuin koltansaamesta ja merisaamesta. Tämä voi viitata siihen, että Lagercrantz muokkasi jossain määrin keräämiään tekstejä. Tekstien muokkaamiseen tai joidenkin piirteiden poisjättämiseen viittaa myös se, ettei teksteissä esiinny kesken jääneitä sanoja tai toistoa lukuun ottamatta niitä tapauksia, joissa sama muoto toistetaan toisella kielellä.

Oskarin ja Ondrein kielellisten repertuaarien eroja on mahdotonta selittää aineiston avulla. Selitystä voidaan kuitenkin yrittää etsiä heidän kielellisten elämänkertojen eroavaisuuksista. Oskar kävi luostarikoulua, jossa hän todennäköisesti tutustui myös sellaisten siidojen kolttasaamelaisiin, joilla koltansaame oli hallitsevana kielenä. Hänellä oli mitä todennäköisemmin myös vahva kielellinen identiteetti, mihin viittaa hänen toimintansa kolttasaamelaisten luottamusmiehenä ja kolttasaamelaisten identiteetille tärkeän ortodoksisen kirkon kirkonvanhimpana. Nämä 
saattoivat osaltaan auttaa häntä pitämään koltansaamea ja merisaamea erossa toisistaan. Tällaisia vahvasta kieli-identiteetistä kertovia seikkoja ei ole säilynyt Ondreista.

\section{AINEISTOSSA ESIINTYVÄT HYBRIDIMUODOT}

Eri tutkimuksissa on osoitettu, että koodien sekoittumisessa voi esiintyä erilaisia hybridimuotoja, joissa yhdistyvät eri kielten elementit. Niitä esiintyy erityisesti lähisukuisten kielten välillä, kuten suomen ja viron (Praakli, 2009) sekä norjan ja englannin välillä (Grimstad ym., 2014), mutta niitä voi esiintyä myös muiden kielten välillä, esimerkiksi ersän ja venäjän välillä (Janurik, 2017).

Joskus hybridimuodoissa voi esiintyä kaksoismorfologiaa, jossa jokin kieliopillinen ilmiö on koodattu molempien kielten kieliopillisilla morfeemeilla. Tällaista kaksoismorfologiaa voi esiintyä sekä sukukielten, kuten suomen ja viron (Praakli, 2009, s. 130-131; Riionheimo \& Frick, 2014), että sellaisten kielten välillä, jotka eivät ole sukukieliä, kuten suomen ja englannin välillä (Kovács, 2009, s. 36) (ks. lisää Kovács \& Janurik, 2018, s. 4446). Käyttämässäni tutkimusaineistossa kaksoismorfologiaa ei kuitenkaan esiinny, mikä voi johtua siitä, että koltansaame ja merisaame ovat niin lähellä muoto-opin ja syntaksin osalta toisiaan, että kieliopilliset rakenteet on yleensä mahdollista korvata morfeemi morfeemilta toisen kielen rakenteiksi.

Sekä Ondrein että Oskarin teksteissä esiintyy jonkin verran sellaisia sananmuotoja, joissa on piirteitä sekä koltansaamesta että merisaamesta. Niitä voi pitää sanansisäisinä vaihtoina. Suurin osa tällaisista hybridimuodoista esiintyy Ondrein koltansaame-merisaame-rekisterin sisällä, mutta yksittäisiä muotoja esiintyy myös muissa rekistereissä. Seuraavassa käsittelen näitä tutkimusaineistossani esiintyviä hybridimuotoja, jotka jaan kahteen osaan: äänteellisiin hybridimuotoihin, joissa sananmuoto sisältää äänteellisiä piirteitä molemmista kielistä, ja kieliopillisiin hybridimuotoihin, eli tapauksiin, joissa yhden kielen sanaa on taivutettu toisen kielen taivutusopin mukaan.

\section{1 Ä̈nteelliset hybridimuodot}

Lagercrantzin keräämissä teksteissä esiintyy sananmuotoja, joissa jokin äännepiirre viittaa koltansaameen ja toinen merisaameen. Tällaisista sananmuodoista on mahdotonta sanoa, kumpaan kieleen ne kuuluvat.

Vokaalien väliset sibilantit ovat itäsaamessa, laadullisen astevaihtelun alaisia mutta länsisaamessa eivät (Korhonen, 1981, s. 18). Koltansaamessa soinnittomat sibilantit vaihtelevat heikossa asteessa soinnillisten sibilanttien kanssa, esim põóssâd :põozzzam 'pestä: pesen', mutta merisaamessa asteivaihtelu näkyy vain sibilantin pituudessa, esim. bassat : basan. Verbimuodossa keezi $i^{6}$ vetää.PRT.3sG (Ondrei ${ }^{7}$; Lagercrantz, 1961, s. 200) keskuskonsonantiston heikossa asteessa esiintyy koltansaamen tavoin soinnillinen sibilantti, mutta ensitavun diftongi on oiennut, kuten merisaamessa, esim. geassit'vetää' : gesii vetää. PRT.3sG. Koltansaamessa ensitavun diftongin oikenemista ei tapahdu, esim. kie'ssed $^{\prime} k_{i e} e^{\prime} z z i$.

Ensitavun diftongi on oiennut merisaamen mukaisesti myös verbimuodossa vuuini nähdä.PRT.3sG (Ondrei; Lagercrantz, 1961, s. 205), vrt. oaidnit : oinnii. Sananmuodossa koltansaameen viittaa sananalkuinen proteettinen $v$, joka esiintyy koltansaamessa alkuperäisen sananalkuisen ${ }^{*}{ }^{-}$edellä, esim. vuei'nne- < kantasaamen *njnē. Lagercrantz

6 Muista koltansaamen murteista poiketen Näätämön murteessa soinniton sibilantti vaihtelee usein heikossa asteessa soinnillisen yksittäissibilantin kanssa (vrt. Sammallahti, 1998, s. 26).

7 Teksteissä esiintyvien hybridimuotojen yhteydessä olen maininnut kummalta Lagercrantzin informantilta muoto on peräisin. 
mainitsee koltansaamea ja merisaamea erottaviksi piirteiksi sananalkuisen proteettisen $v$ :n sekä oientumattoman diftongin $u o$, esim. koltansaame puodi ${ }^{8}$ tulla.PTR.3sG vs. merisaame bodii (Lagercrantz, 1961, s. 172, 173, 188). Lagercrantzin sanakirja-aineistossa esiintyy myös Näätämön murteen oletuksenmukainen muoto vuoini (Lagercrantz, 1939, \$4548), jossa ensitavun diftongi ei ole oiennut.

Ensitavun diftongin oikeneminen esiintyy myös verbimuodossa jeli käydä.PTR.3sG (Ondrei; Lagercrantz, 1961, s. 199), vrt. merisaame eallit : elii. Koltansaameen muodossa viittaa sananalkuinen $\mathrm{j}$-proteesi, joka esiintyy koltansaamessa alkuperäisen ${ }^{*} \bar{\varepsilon}$ edellä esim.

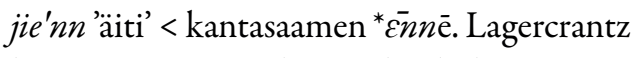
kirjoittaa tämän olevan yksi koltansaamea ja merisaamea erottava piirre (Lagercrantz, 1961, s. 172). Lagercrantz kirjasi muistiin Näätämön koltansaamesta myös odotuksenmukaisen yksikön kolmannen persoonan preteritimuodon jieli (Lagercrantz, 1939, \$856), jossa ensitavun diftongi ei ole oiennut.

Merisaamen toisen tavun labiaalisia vokaaleita $u$ ja $o$ vastaa koltassa $a$ (paitsi jos kyseessä on supistumavokaali; katso tarkemmin Sammallahti, 1998, s. 29), esim. merisaame gorrum ommella.PRT.PTCP vs. koltansaame kuärram. Lagercrantzin koltansaamesta keräämässä aineistossa esiintyvät muodot nizzun nainen.PL (Ondrei; Lagercrantz, 1961, s. 191) sekä nizzunak nainen.PL (Ondrei; Lagercrantz, 1961, s. 198), joiden vokaalit viittaavat merisaameen (nissunak), mutta keskuskonsonantiston soinnillinen sibilantti koltansaameen (neezzan). Koltansaamessa kyseisessä sanassa ei ole astevaihtelua, vaan alkuperäinen heikko aste esiintyy kaikissa muodoissa. Lagercrantzin keräämissä teksteissä esiintyy myös koltansaamen muiden murteiden mukainen muoto neezzan nainen.PL (Ondrei; Lagercrantz, 1961, s. 195)

8 Näätämön murteen ja muiden koltansaamen murteiden vokalismissa esiintyy eroja. Koltansaamen standardikielellä puõ'di. ja sanakirja-aineistossa löytyy lisäksi nizzan 'nainen' : nissnak nainen.PL (Lagercrantz, 1939, \$4180), jossa muista koltansaamen murteista poiketen esiintyy yksikön nominatiivissa heikko aste ja monikon nominatiivissa vahva aste.

Myös verbimuodon leäskoi valaa.PRT.3SG (Ondrei; Lagercrantz, 1961, s. 200) toisen tavun labiaalivokaali viittaa merisaameen, esim. leaikkui kaataa nestettä.PTR.3sG, mutta sen keskuskonsonantiston $s k$ konsonanttiyhtymä viittaa koltansaameen. Kantasaamen konsonanttiyhtymien ${ }^{*} s k{ }^{*} s t$ ja ${ }^{*} s n$ sibilantista on kehittynyt länsisaamessa konsonanttiyhtymä /jh/ (Sammallahti, 1998, s. 6), kuten merisaamen verbissä leaiku- 'kaataa nestettä' $<$ kantasaamen * $l \bar{\varepsilon} s k^{n} n^{-}$, mutta itäsaamessa konsonanttiyhtymän sibilantti on säilynyt, kuten koltansaamen verbissä leäškkad 'kaataa pois'.

\subsection{Kieliopilliset hybridimuodot}

Tutkimusaineistossa esiintyy äänteellisten hybridimuotojen lisäksi sellaisia sanamuotoja, joissa yhden kielen sanaa on taivutettu toisen kielen taivutusopin mukaan. Tekstit sisältävät muutamia sellaisia verbimuotoja, joissa koltansaamen verbinvartaloon on liitetty merisaamen duaalin kolmannen persoonan preteritin taivutuspääte -iga. Verbimuodon urččaiga juosta.PRT.3DU (Ondrei; Lagercrantz, 1961, s. 197) taustalla on koltansaamen verbi urččâd 'juosta', jota ei ole attestoitu merisaamesta, minkä myös Lagercrantz (1961, s. 173, 187) mainitsee. Huomionarvoista on se, että verbinvartalo on vahvassa asteessa, vaikka sekä merisaamessa että koltansaamen pohjoismurteissa duaalin preteritimuodoissa sanavartalo on heikossa asteessa, kuten preesensin yksikön ensimmäisen persoonan muodossa uurčam, jonka Lagercrantz tallensi Näätämöstä (Lagercrantz, 1939, §8261). Tässä tapauksessa odottaisi siis muotoa ${ }^{* *}$ uurćaiga. Verbimuoto sääraskodijga puhua.INK. 
PRT.3DU (Oskar; Lagercrantz, 1961, s. 184) on inkoatiivijohdos koltansaamen verbistä särnnad 'puhua', jonka todistaa, se että sibilanttialkuinen inkoatiivijohdin -skue'tted ${ }^{9}$ on liittynyt sanavartalon heikkoon asteeseen toisin kuin merisaamessa, jossa parillistavuisilla verbeillä sibilantiton inkoatiivijohdin -goabtit liittyy vahvaan vartaloon. Sanan heikossa asteessa esiintyy äännekehitys $r n>r$ joka esiintyy, koltansaamen pohjoismurteissa särnnad 'puhua' (Itkonen, 1958, s. 475) lisäksi ainakin sanassa pä'rnn 'poika' (Itkonen, 1958, s. 340). Myös Lagercrantz mainitsee tämän koltansaamea ja merisaamea erottavaksi piirteeksi (Lagercrantz, 1961, s. 173, 188). Johdettua koltansaamen verbinvartaloa on taivutettu merisaamen mukaisesti, mihin viittaa duaalin kolmannen persoonan preteritin taivutuspäätteen -iga lisäksi diftongin oikeneminen, vrt. sárnnugoahtit : sárnnugođiiga.

Aineistossa esiintyy myös merisaamen verbi, jota on taivutettu koltansaamen taivutusopin mukaisesti. Verbimuodossa bábtarin paeta.PRT.3DU (Ondrei; Lagercrantz, 1961, s. 198) merisaamen verbiin bábtarit on liittynyt koltansaamen duaalin pääte -in. Tätä verbiä ei tavata koltansaamessa. On hyvä huomata, että muoto báhtarin voi olla myös merisaamen yksikön ensimmäisen persoonan preteritimuoto. Kyseisessä lausekontekstissa tämä ei kuitenkaan tule kysymykseen.

Nominimuodossa kuõskkii koski.ILL (Ondrei; Lagercrantz, 1961, s. 198) koltansaamen substantiiviin kuõskk on liittynyt merisaamen yksikön illatiivin pääte -(i)i. Keskuskonsonantistossa $s k k$ esiintyvä sibilantti osoittaa, että kyseessä on koltansaamen eikä merisaamen nomini guoika (ks. yllä). Huomionarvoista muodossa on se, että ensitavun diftongi ei ole oiennut, kuten merisaamen yksikön illatiivissa guikii, vaan se on säilynyt, kuten koltansaa-

9 Inkoatiivijohdin sisältää tavallisesti suhusibilantin -skue'tted.

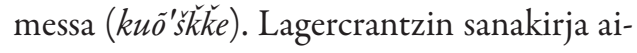
nestossa esiintyy myös muiden koltansaamen murteiden mukainen yksikön illatiivimuoto kuóš̌k (Lagercrantz, 1939, \$2870).

Kuten yllä esitellyistä esimerkeistä käy ilmi, koltansaamen ja pohjoisaamen välisiä kieliopillisia hybridimuotoja on muodostettu hyvin erilaisin keinoin. Sanavartalossa voi tapahtua joko koltansaamen tai merisaamen mukaisia morfofonologisia muutoksia tai vartalo voi olla muodossa, joka on vieras molemmille kielille, kuten verbimuodossa určcaiga juosta. PRT.3DU. Koska suurin osa hybridimuodoista esiintyy Ondrein koltansaame-merisaamerekisterissä, tämä vahvistaa yllä esiteltyä päätelmää siitä, että rekisteri sisältää kongruenttia leksikalisaatiota eikä koodinupotuksia.

\section{TULOKSET}

Tässä artikkelissa tarkastelin koltansaamen ja merisaamen välistä koodien sekoittumista teksteissä, jotka Eliel Lagercrantz keräsi vuonna 1920 Norjan Näätämössä kahdelta kolttasaamelaiselta, jotka puhuivat sekä koltansaamea että merisaamea.

Vaikka sekä Oskar että Ondrei puhuivat koltansaamea ja merisaamea, heidän kielelliset repertuaarinsa erosivat toisistaan. Oskar puhui merisaamen lisäksi koltansaamea, kun taas Ondrei käytti merisaamen lisäksi rekisteriä, jota kutsun koltansaame-merisaamerekisteriksi. Teksteissä ei ole havaittavissa muiden kielten vaikutusta, vaikka muiden alueen koltansaamelaisten tavoin he osasivat myös muita kieliä. Ainakin Oskar puhui venäjää, jota hän oli oppinut kirkkokoulussa, ja sekä Oskar että Ondrei puhuivat mitä todennäköisemmin myös suomea sekä mahdollisesti norjaa. Joko he pitivät muut kielet erossa koltansaamesta ja merisaamesta tai Lagercrantz jätti näiden kielten vaikutuksen kirjoittamatta.

Oskarin ja Ondrein puhumassa merisaa- 
messa on vain yksittäisiä koodinupotuksia koltansaamesta. Oskarin puheessa koodinupotukset sisältävät yksittäisiä nominimuotoja sekä partikkelin $\check{s} e$ 'myös'. Ondrein puheessa koodinupotukset ovat hieman yleisempiä kuin Oskarin puheessa. Ne koostuvat enimmäkseen tavallisista verbimuodoista sellaisista verbeistä, jotka ovat yhteisiä koltansaamelle ja merisaamelle, esim. puó'di, vrt. merisaame bođii. Uskoakseni nämä eivät aiheuttaneet kommunikaatio-ongelmia merisaamen puhujien kanssa muotojen läheisyyden vuoksi.

Oskarin puhuma koltansaame sisältää koodinupotuksia merisaamesta. Ne koostuvat yksittäisistä sanoista tai lausekkeista. Kaikki hänen puhumassa koltansaamessa esiintyvät moniosaiset numeraalit ovat merisaamesta. Aineisto on kuitenkin liian pieni, jotta sen perusteella voisi sanoa, onko kyseessä koodinupotus vai ovatko numeraalit lainattu merisaamesta koltansaameen.

Ondrein puhuma koltansaame-merisaame-rekisterin sisältämää koodien sekoittumista voidaan kutsua kongruentiksi leksikalisaatioksi. Sitä leimaavat jatkuvat vaihdot koltansaamen ja merisaamen välillä, niin että sekä sanasto että kielioppi tulevat molemmista kielistä, minkä mahdollistaa se, että koltansaame ja merisaame ovat typologisesti samankaltaisia lähisukukieliä, joiden lauseopilliset ja morfologiset rakenteet vastaavat pitkälti toisiaan. Tällöin on mahdollista korvata yhden kielen morfeemeja toisen kielen morfeemeilla ilman, että kieliopillinen rakenne rikkoutuisi.

Sekä Oskarin että Ondrein teksteissä esiintyy hybridimuotoja, jotka jaan kahteen osaan: äänneopillisiin hybridimuotoihin, jotka sisältävät äännepiirteitä molemmista kielistä, sekä kieliopillisiin hybridimuotoihin, joissa yhden kielen sanaa on taivutettu toisella kielellä. Tällaiset sanat voivat olla peräisin kummasta kielestä tahansa. Hybridimuodot ovat erityisen yleisiä Ondrein koltansaame-merisaamerekisterissä.

\section{LOPUKSI}

Kuten tutkimuksessa kävi ilmi, koltansaamen ja merisaamen välinen kieliraja ei ole ollut erityisen korkea ainakaan Näätämön kieliyhteisössä. Molempia kieliä hallitsevat puhujat ovat yhdistelleet kielellisessä repertuaarissaan olevia kieliä eri tavoin, minkä myötä merisaamesta on myös lainattu koltansansaameen niin sanastoa kuin kieliopillisia aineksiakin. Jatkossa koltansaamen ja merisaamen kontakteja olisi syytä tutkia Mikko Korhosen 1960-luvulla tekemien nauhoitusten pohjalta. Tutkimus antaisi lisätietoa sekä kielikontakteista että valottaisi edelleen huonosti kuvatun koltansaamen läntisimmän murteen erityispiirteistä ja suhdetta ympäröiviin kielimuotoihin.

Saamelaiskielet ovat muodostaneet keskisestä skandinaviasta Kuolan niemimaan kärkeen ulottuvan murrejatkumon. Vaikka tämä murrejatkumo on monin paikoin katkennut ja monet ennen monikieliset yheisöt ovat valtakielistyneet, muuttoliikkeiden myötä on syntynyt myös uusia monikielisiä yhteisöjä. Erityisesti Pohjoismaissa löytyy vielä kieliyhteisöjä, joissa eri saamelaiskieliä käytetään rinnakkain. Esimerkiksi Pohjois-Ruotsissa on kuntia, joissa puhutaan sekä pohjoissaamea että luulajansaamea, ja Suomen puolella Inarin kunnan virallisia kieliä on suomen lisäksi, pohjoissaame, inarinsaame sekä koltansaame. Näissä yhteisöissä eri saamelaiskielten käyttämistä rinnakkain on alettu suosia uudella tavalla. Esimerkiksi YLE Sápmin radio- ja televisiolähetyksissä eri kieliä käytetään niin ohjelmien juontamisessa kuin keskusteluissakin (Aikio-Puoskari, 2016, s. 84-85). Tällainen toiminta luo vähemmistökielille uusia käyttöaloja. Samalla se myös lisää saamelaiskielten välisiä kielikontakteja. On oletettavaa, että myös näissä kontakteissa eri puhujat käyttävät eri tavoin kielellistä repertuaariaan, mutta asiaa olisi syytä tutkia. 


\section{KÄYTETYT LYHENTEET}

\begin{tabular}{|l|l|}
\hline 3 kolmas persoona & KOM komitatiivi \\
\hline AKK akkusatiivi & KOMP komparatiivi \\
\hline AKT aktiivi & NEG kielto \\
\hline ATTR attribuutti & ORD järjestysluku \\
\hline DU duaali & PL monikko \\
\hline ESS esiivi & PRT preteriti \\
\hline GEN genetiivi & PARTIS partisiippi \\
\hline ILL illatiivi & REFL refleksiivipronomini \\
\hline INK inkoatiivi & SG yksikkö \\
\hline KON konnegatiivi & SUP superlatiivi \\
\hline
\end{tabular}

\section{KÄYTETTY AINEISTO}

Lagercrantz, E. (1961). Lappische Volksdichtung $V$ See- und skolte-lappische Texte des südlichen Varangergebiets. Suomalais-Ugrilaisen Seuran Toimituksia 124. Helsinki: Suomalais-Ugrilainen Seura.

\section{LÄHTEET}

Aikio-Puoskari, U. (2016). Gullos sámegiella! Saamen kielten elvyttämisen parbaita käytäntöjä ja kansallisen politiikan linjauksia Suomessa, Ruotsissa ja Norjassa. Inari: Sámediggi/Saamen kielen toimisto.

Clyne, M. (1987). Constraints on code switching: How universal are they? Linguistics, 25, 739-764.

Feist, T. (2015). A Grammar of Skolt Saami. Suomalais-Ugrilaisen Seuran Toimituksia 273. Helsinki: Suomalais-Ugrilainen Seura.

Frick, M.; Grünthal, R. \& Praakli, K. (2018). A linguistic encounter between neighbors and relatives: Reconnecting Estonian and Finnish in terms of contemporary multilingualism. Teoksessa O. Táncos, M. Kovács, U. Puura (toim.), Multilingual practices in Finno-Ugric communities. Uralica Helsingiensia 13, (s. 163-196). Helsinki: Suomalais-Ugrilainen Seura.

Friis, J. A. (1856). Lappiske Sprogprover. En Samling aflappiske Eventyr, Ordsprogog Gaader. Med Ordbog. Christiania: J. W. Cappelens Forlag.

Grimstad ym. (2014). = Grimstad, M. B., Lohndal, T., Åfarli, T. A.: Language mixing and exos- keletal theory: A case study of word-internal mixing in American Norwegian. Nordlyd Vol 41, No 2, s. 213-237. Tromsø: Utviklet og tilrettelagt av Universitetsbiblioteket i Tromsø.

Itkonen, T. I. (1958). Koltan- ja kuolanlapin sanakirja. Wörterbuch des Kolta- und Kolalappischen. I-II. Lexica Societatis Fenno-Ugricae XV. Helsinki: Suomalais-Ugrilainen Seura.

Janurik, B. (2017). Erzya-Russian bilingual discourse: A structural analysis of intrasentential code-switching patterns. Szeged: Szegedi Tudományegyetem. Tohtorinväitöskirja.

Johansson, L. (1998). Code-copying in IranoTurkic. Language Sciences 20, s. 325-337.

Korhonen, M. (1964). Lapin murteiden keskinäisistä suhteista. Vuosikirja 5, s. 49-64. Lapin tutkimusseura.

Korhonen, M. (1981). Johdatus lapin kielen historiaan. Suomalaisen Kirjallisuuden Seuran Toimituksia 370. Helsinki: Suomalaisen Kirjallisuuden Seura.

Kovács, M. (2001). Code-switching and language shift in Australian Finnish in comparison with Australian Hungarian. Åbo: Åbo Akademi University Press.

Kovávs, M. (2009). Koodinvaihto ja kielioppi. Teoksessa J. Kalliokoski, L. Kotilainen, P. Pahta (toim.), Kielet kohtaavat, (s 24-49). Tietolipas 227. Helsinki: Suomalaisen Kirjallisuuden Seura.

Kovács, M.; Janurik, B. (2018). Grammatical and sociolinguistic aspects of code-switching in 
Finno-Ugric languages. Teoksessa O. Táncos, M. Kovács, U. Puura (toim.), Multilingual Practices in Finno-Ugric Communities, (s. 13-76). Uralica Helsingiensia 13. Helsinki: SuomalaisUgrilainen Seura.

Lagercrantz, E. (1929). Sprachlehre des Nordlappischen nach den seelappischen Mundarten. Oslo: Oslo etnografiske museum.

Lagercrantz, E. (1939). Lappischer Wortschatz I-II. Lexica Societatis Fenno-Ugricae VI. Helsinki: Suomalais-Ugrilainen Seura.

Lagercrantz, E. (1950). Laulava Lappi. Tunturinkävijän ja tutkijan elämyksiä ja mietteitä. Porvoo: WSOY.

Lunde, A. (1979). Sør-Varangers historie. Vadsø: Sør-Varanger kommune.

Lähteenmäki, M. (2004). Kalotin kansaa. Rajankäynnit ja vuorovaikutus Pohjoiskalotilla 18081889. Historiallisia Tutkimuksia 220. Helsinki: Suomalaisen Kirjallisuuden Seura.

Matras, Y (2009). Language contact. Cambridge : Cambridge University Press.

Miestamo, M. (2011). Skolt Saami: A typological profile. Suomalais-Ugrilaisen Seuran Aikakauskirja 93, s. 111-145.

Muysken, P. (2000). Bilingualspeech. A typology of code-mixing. Cambridge: Cambrige University Press.

Myers-Scotton, C. (1993). Duelling languages: Grammaticalstructure in codeswitching. Oxford:
Oxford University Press.

Pennanen, J. \& Näkkäläjärvi, K. (2000). Siiddastallan: siidoista kyliin: luontosidonnainen saamelaiskulttuuri ja sen muuttuminen. Oulu: Pohjoinen.

Pineda, D. (2018) “Куэссь не получается са̄мас, рӯшас полегче" - codeswitching on the Kola Peninsula. Полярный вестник 11, s. 47-62.

Praakli, K. (2009). Esimese põlvkonna Soome eestlaste kakskeelne keelekasutusja koodikopeerimine. Dissertationes philologiae estonicae universitatis tartuensis 24. Tartu: Tartu Ülikooli Kirjastus.

Riionheimo, H., Frick, M. (2014). The emergence of Finnish-Estonian bilingual constructions in two contact settings. Sociolinguistics 8, No 3 409-447.

Sammallahti, P. (1998). Saami languages. An Introduction. Kárášjohka: Davvi Girji.

Sarhimaa, A. (1999). Syntactic transfer, contactinduced change, and the evolution of bilingual mixed codes: Focus on Karelian-Russian language alternation. Studia Fennica Linguistica 9. Helsinki: Suomalaisen Kirjallisuuden Seura.

Turunen, M. (1997). Nykyvatjan koodinvaihdosta. Virittäjä 101, 208-232.

Wikan, S. (1995). Grensebygda Neiden. Mote mellom folkegrupper og kampen om ressursene. Nordkalott-Forlaget. Sør-Varanger museums forlag. 


\section{CODE-MIXING BETWEEN SKOLT SAAMI NEIDEN DIALECT AND SEA SAAMI}

Markus Juutinen, University of Oulu, Giellagas-institute

In this paper I study code-mixing between Skolt Saami Neiden dialect and North Saami Sea Saami dialect. The material I use contains texts from two bilingual speakers collected in Neiden Norway in year 1920. The collector Eliel Lagercrantz describes some of the texts as Sea Saami and the others as mixed language of Skolt Saami and Sea Saami.

In the study I found out that the texts contain three different registers: Sea Saami, Skolt Saami, and a register I call as Skolt Saami-Sea Saami. Skolt Saami and Sea Saami registers contain short insertions from other language. The Skolt Saami-Sea Saami register contain both grammar and vocabulary from both languages. I call this as conguent lexicalization which means that a speaker can fill the grammatical stuctures shared by the languages with the vocabulary of Skolt Saami and North Saami. In the study I also found out that the texts contain hybrid wordforms. Phonetical hybrid forms have phonetical features from both languages. In grammatical hybrid forms a word from one language is conjugated in the other language.

Keywords: code-mixing, language contacts, North Saami, Skolt Saami 